\title{
INFLUENCE OF DENTAL PROSTHETICS TECHNOLOGY ON THE DYNAMICS OF EARLY PREDICTORS OF DESTRUCTIVE INFLAMMATORY PROCESS IN THE PERIIMPLANT ZONE
}

Tlustenko VP, Bayrikov IM, Trunin DA, Gusyakova OA, Komlev SS $\bowtie$

Samara State Medical University, Samara, Russia

An objective assessment of the morphofunctional characteristics of the state of soft tissues and bone structures adjacent to the dental implant allows to control the dynamics of the processes of osseointegration in the jaw-dental implant system. The aim of the work was to investigate the level of the $\beta$-CrossLaps, C-reactive protein (CRP), osteocalcin markers after orthopedic treatment of patients using dental implant supported advanced dental restoration technologies, to perform a biochemical analysis of the oral fluid of patients after restoration using dental implants and new two-part dental implants. In patients of the index group (52 people), the removable prostheses with metal frame and fixing elements or the commercially available dental implant supported removable prostheses were installed. For the patients of the control group (12 people), the commercially available dental implant supported removable prostheses of acrylic plastics were constructed. For all the patients after 6 months the level of $\beta$-CrossLaps, CRP, osteocalcin markers in the oral fluid was analysed. In patients of the index group, the average content of $\beta$-CrossLaps was $0.0126 \pm 0.002 \mathrm{ng} / \mathrm{ml}$, in the control group it was $0.0147 \pm 0.002 \mathrm{ng} / \mathrm{ml}$. The average content of the CRP in patients of the index group was $0.358 \pm 0.019 \mathrm{mg} / \mathrm{l}$, in patients of the control group it was $0.78 \pm 0.01 \mathrm{mg} / \mathrm{l}$. In patients of the index group, the average content of osteocalcin was $1.46 \pm 0.25 \mathrm{ng} / \mathrm{ml}$, in the control group it was $1.98 \pm 0.31 \mathrm{ng} / \mathrm{ml}$. It has been shown that biochemical markers of the oral fluid can be used to predict complications after the dental implants installation. Restoration with two-part dental implants of modern design is associated with fewer complications.

Keywords: removable dental prostheses, two-part dental implant, $\beta$-CrossLaps, CRP, osteocalcin metabolic markers

Author contribution: Tlustenko VP, Bayrikov IM, Trunin DA, Komlev SS - concept and research design, surgical and orthopedic treatment of patients; Gusyakova OA, Bayrikov IM, Komlev SS - collection and processing of material, biochemical analysis of oral fluid, statistical processing of results.

Compliance with ethical standards: the study was approved by the Ethics Committee of Samara State Medical University (protocol № 2018/196). All patients signed a voluntary informed consent to participate in the study (dental implantation and orthopedic treatment, collection of oral fluid samples).

Correspondence should be addressed: Sergey S. Komlev

Chapayevskaya 89, Samara, 443099; stomat.ks@mail.ru

Received: 27.11.2018 Accepted: 03.04.2019 Published online: 13.04.2019

DOI: $10.24075 /$ brsmu.2019.025

\section{ВЛИЯНИЕ ТЕХНОЛОГИИ ПРОТЕЗИРОВАНИЯ ЗУБОВ НА ДИНАМИКУ РАННИХ ПРЕДИКТОРОВ ВОСПАЛИТЕЛЬНО-ДЕСТРУКТИВНОГО ПРОЦЕССА В ПЕРИИМПЛАНТАТНОЙ ЗОНЕ}

\author{
В. П. Тлустенко, И. М. Байриков, Д. А. Трунин, О. А. Гусякова, С. С. Комлев
}

Самарский государственный медицинский университет, Самара, Россия

\begin{abstract}
Объективная оценка морфофункциональных характеристик состояния мягких тканей и костных структур, прилежащих к дентальному имплантату, позволяет контролировать динамику процессов остеоинтеграции в системе челюсть - дентальный имплантат. Целью работы было исследовать уровни маркеров $\beta$-CrossLaps, C-реактивный белок (СРБ), остеокальцина после ортопедического лечения пациентов с применением усовершенствованных технологий протезирования зубов с опорой на дентальные имплантаты. Провести биохимический анализ ротовой жидкости пациентов после протезирования на дентальных имплантатах и новых разборных дентальных имплантатах. Пациентам основной группы (52 человека) изготовили съемные ортопедические конструкции с металлическим каркасом и фиксирующими элементами с опорой на разборные дентальные имплантаты и съемные ортопедические конструкции с опорой на серийно выпускаемые дентальные имплантаты. Для пациентов контрольной группы (12 человек) были изготовлены съемные ортопедические конструкции из акриловых пластмасс с опорой на дентальные имплантаты, выпускаемые серийно. Всем пациентам через 6 месяцев исследовали уровни маркеров $\beta$-CrossLaps, CPБ, остеокальцина в ротовой жидкости. У пациентов основной группы содержание $\beta$-CrossLaps в среднем составило 0,0126 \pm 0,002 нг/мл, в контрольной группе - 0,0147 \pm 0,002 нг/мл. Содержание СРБ у пациентов основной группы

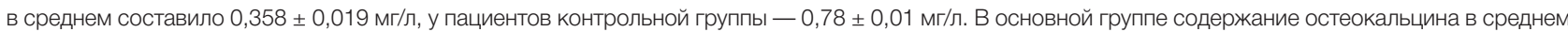
составило 1,46 \pm 0,25 нг/мл, в контрольной группе пациентов - 1,98 \pm 0,31 нг/мл. Показано, что биохимические маркеры ротовой жидкости можно использовать для прогнозирования осложнений после установки дентальных имплантатов. Протезирование усовершенствованными конструкциями на разборных дентальных имплантатах сопряжено с меньшим количеством осложнений.
\end{abstract}

Ключевые слова: съемные ортопедические конструкции, разборный дентальный имплантат, метаболические показатели $\beta$-CrossLaps, CPБ, остеокальцин Информация о вкладе авторов: В. П. Тлустенко, И. М. Байриков, Д. А. Трунин, С. С. Комлев - разработка концепции и дизайна исследования, хирургическое и ортопедическое лечение пациентов; О. А. Гусякова, И. М. Байриков, С. С. Комлев - сбор и обработка материала, биохимическое исследование ротовой жидкости, статистическая обработка результатов.

Соблюдение этических стандартов: исследование одобрено этическим комитетом Самарского государственного медицинского университета (протокол № 2018/196). Все пациенты подписали информированное согласие на участие в исследовании (проведение операции дентальной имплантации и ортопедическое лечение, сбор образцов ротовой жидкости).

Для корреспонденции: Сергей Сергеевич Комлев

ул. Чапаевская, д. 89, г. Самара, 443099; stomat.ks@mail.ru

Статья получена: 27.11.2018 Статья принята к печати: 03.04.2019 Опубликована онлайн: 13.04.2019

DOI: $10.24075 /$ vrgmu.2019.025

When treating patients with partial and complete absence of teeth using dental implant supported prostheses, it is important to plan the surgical intervention, select the implant system and the prosthesis, predict the outcome of the chosen set of measures. An objective assessment of the morphological and functional characteristics of the state of soft tissues and bone structures adjacent to the dental implant is essential. It allows to prevent errors that can lead to disruption of the processes 
of osseointegration in the jaw - dental implant system and contribute to the development of early and late destructive inflammatory complications [1].

After installation of commercially available dental implants, two-part dental implants and orthopedic treatment with improved prostheses, it is necessary to study the factors that serve as indicators of the preclinical stage of development of inflammatory destructive disorders. For this purpose, the studies of the oral fluid as a biological media that provides homeostasis of the tissues in the periimplant zone are conducted [2-4].

The regeneration of bone tissue around the implant after a dental implantation operation is a combination of processes of structural and functional recovery after damage. The process of ossification is based on the mechanisms of transformation of undifferentiated cells into osteoblasts, the process of osteoinduction, as well as the emergence of a matrix that ensures the deposition of bone stock. Indicators reflecting the processes of destruction and the state of mineralizationdemineralization of bone tissue include osteocalcin, C-reactive protein (CRP), the cleavage product of $\mathrm{C}$-telopeptide of the I type collagen ( $\beta$-CrossLaps) [5-8].

Osteocalcin is a non-collagen calcium-binding protein of the bone matrix, consisting of 49 amino acid residues. It is synthesized almost exclusively by osteoblasts and is involved in the processes of mineralization, it is a marker of bone remodeling. $\beta$-CrossLaps is a bone resorption marker. $\mathrm{CRP}$ is a typical protein of the acute phase of inflammation, which is considered to be the most sensitive laboratory marker of infection, inflammation and tissue damage. In its structure, the CRP consists of five identical polypeptide subunits, forming a cyclic disc-shaped pentameric structure. Synthesis of CRP occurs in hepatocytes and is regulated by anti-inflammatory cytokines. In presence of inflammation, infection, or traumatic injury, the CRP levels quickly increase. In the oral fluid, the level of CRP reaches its maximum 24 hours after activation of its synthesis in hepatocytes, [9-12].

Complications of dental implantation occur in $6-23 \%$ of cases. According to epidemiological studies data, in patients who use dental implant supported prostheses for a long time, the signs of mucositis are present in $80 \%$ of cases, and the signs of periimplantitis are present in $28-56 \%$ cases. Clinical manifestations of dental periimplantitis are predicated by the presence of the destructive inflammatory process. A significant number of publications shows the great informative value of the qualitative and quantitative assessment of indicators of the oral fluid of patients, and the ability to use indicators of oral fluid as a prognostic instruments for dental implantation [13-15].

The aim of the work was to determine the levels of the $\beta$-CrossLaps, CRP, osteocalcin markers after orthopedic treatment of patients using advanced implant supported restoration techniques.

\section{METHODS}

The study included 52 patients of the index group and 12 patients of the control group. Criteria for inclusion of patients in the study: any gender; partial absence of teeth, Kennedy class I and II. Exclusion criteria: dentofacial anomalies; the presence of diseases of the endocrine system and of the gastrointestinal tract.

Patients of the index group were divided into two subgroups: index group 1 and index group 2. Index group 1 included 12 patients: 4 men and 8 women aged $45-65$ years. In the patients of this group, the removable prostheses with a metal frame and fixing elements were installed. Telescopic crowns and clasps were used. 28 two-part dental implants of our design (Patent of Russian Federation № 2593349) were installed.

Index group 2 included 40 patients: 15 men and 25 women aged $45-65$ years. In patients of this group, the commercially available dental implant supported removable prostheses (85 dental implants) were installed. The fixing elements were located in the metal frame of the removable prosthesis.

For the patients of the index group, the removable prostheses were constructed of thermoplastics, nylon with a metal frame (Patent of Russian Federation № 2588488). Introduction of molded frame into thermoplastic made it possible to evenly distribute the load on the abutment teeth and dental implants, to obtain the possibility of stabilization along the plane, to improve the fixation of the prosthesis.

The control group included 12 patients: 3 men and 9 women aged 45-65 years, for whom the commercially available dental implant supported removable prostheses made of acrylic plastics were constructed. The fixing elements were located in the basis of a removable prosthesis; depending on the defect of the dental arcade, 2-3 dental implants were installed.

When examining patients, the dental status was assessed. All participants were subjected to biochemical analysis of oral fluid samples by determining the following metabolic parameters: $\beta$-CrossLaps, CRP, osteocalcin. Study of the metabolic processes of oral homeostasis is a non-invasive research method. Evaluation of metabolic processes in the bone tissue of patients of control and index groups was performed 6 months after orthopedic treatment. At the stage of biochemical analysis of saliva, patients did not have signs of acute somatic diseases.

The quantitative analysis of $\beta$-CrossLaps and osteocalcin in the oral fluid was performed by the solid-phase tube method with ECL reaction on the basis of the streptavidinbiotin technology with ruthenium label using the Elecsys-2010 (F. Hoffmann-La Roche; Switzerland) automatic ECL laboratory unit. Evaluation of CRP was performed on the Cobas Integra 400 plus (F. Hoffmann-La Roche; Switzerland) biochemical analyzer. The following diagnostic kits (F. Hoffmann-La Roche; Switzerland) were used: a set of calibrators for evaluation of $\beta$-CrossLaps, N-MID osteocalcin, a reagent kit for quantitative analysis of $\beta$-CrossLaps, N-MID osteocalcin, C-reactive protein Lx.

Statistical processing of the obtained data was performed using Student's t-test on a personal computer running the Microsoft Windows 10 operating system using the SPSS Statistics 21.0 (license № 20130626-3; USA) statistical software package.

The parametric Student's t-test was used, as well as the Kruskal-Wallis one-way analysis of variance and the MannWhitney U-test.

\section{RESULTS}

The table presents the values of metabolic parameters of samples of oral fluid from patients of the control and index groups taken 6 months after orthopedic treatment.

In the index group, the average content of $\beta$-CrossLaps in the oral fluid was $0.0126 \pm 0.002 \mathrm{ng} / \mathrm{ml}$, in the control group it was $0.0147 \pm 0.002 \mathrm{ng} / \mathrm{ml}$. During the bone resorption, telopeptides with remnants of collagen molecules enter the oral fluid.

In the index group, the average content of CRP was $0.358 \pm 0.019 \mathrm{mg} / \mathrm{l}$, in the control group it was $0.78 \pm 0.01 \mathrm{mg} / \mathrm{l}$.

To assess the metabolic processes in the bone tissue of patients after orthopedic treatment, we evaluated the osteocalcin content in the oral fluid. In the index group, the 
Table 1. $\beta$-CrossLaps, CRP, osteocalcin metabolic markers in patients of the control and index groups 6 months after dental implantation

\begin{tabular}{|c|c|c|c|c|}
\hline \multirow{2}{*}{ Parameters } & \multirow{2}{*}{ Reference values } & \multicolumn{2}{|c|}{ Index group } & \multirow{2}{*}{ Control group } \\
\cline { 3 - 5 } & & 1 & 2 & \multirow{2}{*}{$0.0147 \pm 0.002$} \\
\hline$\beta$-CrossLaps $(\mathrm{ng} / \mathrm{ml})$ & $0.01 \pm 0.001$ & $0.0123 \pm 0.002^{*}$ & $0.0128 \pm 0.002^{*}$ & $0.78 \pm 0.01$ \\
\hline CRP $(\mathrm{mg} / \mathrm{l})$ & $0.1 \pm 0.001$ & $0.241 \pm 0.013^{*}$ & $0.476 \pm 0.024^{*}$ & $1.98 \pm 0.31$ \\
\hline Osteocalcin $(\mathrm{ng} / \mathrm{ml})$ & $1.11 \pm 0.11$ & $1.33 \pm 0.26^{*}$ & $1.58 \pm 0.24$ & \\
\hline
\end{tabular}

Note: * 一 the significance of differences compared to the data of the control group $(p<0.05)$.

average value was $1.46 \pm 0.25 \mathrm{ng} / \mathrm{ml}$, in the control group the average value was $1.98 \pm 0.31 \mathrm{ng} / \mathrm{ml}$. Osteocalcin, the bone matrix protein, containing the $\mathrm{y}$-carboxyglutamic acid, promotes the fixation of calcium ions and enables mineralization. Osteocalcin exhibits chemotactic properties in relation to the precursor cells of osteoblasts and osteoclasts, attracting them to the osteogenesis zone.

In the index group, the biochemical parameters in 3 patients had the following values: $\beta$-CrossLaps $-0.0295 \pm 0.002 \mathrm{ng} / \mathrm{ml}$, $\mathrm{CRP}-1.17 \pm 0.03 \mathrm{mg} / \mathrm{l}$, osteocalcin $-2.92 \pm 0.11 \mathrm{ng} / \mathrm{ml}$. In the control group, in 3 patients there were the following values: $\beta$-CrossLaps - $0.0463 \pm 0.002 \mathrm{ng} / \mathrm{ml}$, CRP $-1.49 \pm 0.01 \mathrm{mg} /$, osteocalcin $-3.11 \pm 0.17 \mathrm{ng} / \mathrm{ml}$. The obtained values of metabolic parameters of patients of the control group indicate presence of characteristic for periimplantitis destructive processes in the bone tissue. The number of complications in the index and control groups of patients was 5.8 and $16.7 \%$, respectively.

\section{DISCUSSION}

The state of oral homeostasis after the dental implantation operation was studied by determining indicators of the metabolism of the oral fluid of patients in the control and index groups, reflecting the presence of destruction processes, the state of mineralization and demineralization of bone tissue. The study of early predictors $[2,6,11]$ of the destructive inflammatory process in the periimplant zone allows to control the dynamics of the processes of osseointegration in the jaw dental implant system. Metabolic indices of $\beta$-CrossLaps, CRP, osteocalcin reflected the intensity of the inflammatory response characteristic of the traumatic process during the dental implantation operation.

CRP analysis is an objective method of screening the inflammatory activity in patients of the control and index groups after dental implantation using commercially available dental implants, two-part dental implants and after orthopedic treatment using improved prostheses.

To assess the metabolic processes in the bone tissue of patients after dental implantation, we evaluated the osteocalcin content.

The method of studying oral fluid as the main homeostatic environment of the oral cavity objectively reflected the response of oral tissues during destructive inflammatory processes that occurred in patients of the control and index groups after the dental implantation operation. In the presence of minor inflammatory events, changes in the metabolic indices of the oral fluid occurred associated with the delivery of the destroyed protein macromolecules fragments, the insufficiently oxidized metabolic products.

An increase in the level of osteocalcin in the oral fluid indicated a decrease in the mineralization in the periimplant zone and the plastic resources of the bone tissue in patients of the control group. The increased content of CRP reflects the severity of the inflammatory response, which allows to obtain additional evaluation criteria for characterizing the pathological process. Patients in the control group after 3 months of antiinflammatory and antimicrobial therapy experienced a decrease in the level of biochemical parameters.

Lower levels of inflammation in patients of the index group compared to the control group are attributed to the use of improved prostheses and fixing elements supported by titanium abutments of the two-part dental implants.

When analyzing the results of osteomatrix protein content in saliva, a rapid increase in $\beta$-CrossLaps decay fragments and an increase in the concentration of osteocalcin and CRP were found. These data indicate the specificity of the revealed violations of the biochemical composition of the oral fluid during the acceleration of osteoclastic processes in patients with complications.

A characteristic indicator of enhanced bone resorption is an established increase of the content of collagen fragments ( $\beta$-CrossLaps), osteocalcin, CRP.

\section{CONCLUSION}

The results of our research confirmed that metabolic markers such as $\beta$-CrossLaps, CRP, osteocalcin, in patients after dental implantation are informative for predicting complications when using different types of dental implants. A lower percentage of complications and a smaller deviation from normal level of the inflammation indicators in patients of the index group compared to the control group are presumably associated with the use of improved prostheses and fixing elements supported by titanium abatments of the two-part dental implants.

\section{References}

1. Aziz S. Hard and soft tissue surgical complications in dental implantology. Oral Maxillofac. Surg Clin North Am. 2015; 27 (2): 313-8.

2. Guobis Z, Pacauskiene I, Astramskaite I. General diseases influence on peri-implantitis development: a systematic review. J Oral Maxillofac Res. 2016; 7 (5): 9-14.

3. Lohmann $\mathrm{CH}$, Rampal S, Lohrengel M, Singh G. Imaging in periprosthetic assessment: an orthopaedic perspective. EFORT Open Rev. 2017; 2 (5): 117-25.

4. Greenstein G, Carpentieri J, Cavallaro J. Nerve damage related to implant dentistry: incidence, diagnosis, and management. Compend Contin Educ Dent. 2015; 36 (9): 652-9. 
5. Alikhasi M, Alsharbaty MHM, Moharrami M. Digital Implant Impression Technique Accuracy: A Systematic Review. Implant Dent. 2017; 26 (6): 929-35. DOI: 10.1097/ID.0000000000000683.

6. Atrushkevich VG, Shkolnaya KD. Osobennosti mineral'nogo i kostnogo obmena u pacientov $\mathrm{v}$ zavisimosti ot haraktera techenija parodontita. Lechenie i profilaktika. 2017; 2 (22): 85-92.

7. Alrabeah GO, Brett $P$, Knowles JC, Petridis $\mathrm{H}$. The effect of metal ions released from different dental implant-abutment couples on osteoblast function and secretion of bone resorbing mediators. J Dent. 2017; 66: 91-101. DOI: 10.1016/j.jdent.2017.08.002.

8. Boronat-Catala M, Catala-Pizarro M, Bagan Sebastian J. Salivary and crevicular fluid interleukins in gingivitis. J Clin Exp Dent. 2014; 6 (1): 175-9.

9. Casado PL, Aguiar DP, Costa LC. Different contribution of BRINP3 gene in chronic periodontitis and periimplantitis: a cross-sectional study. BMC Oral. Health. 2015; (15): 33. DOI 10.1186/s12903015-0018-6.

10. Plyuhin DV. Soderzhanie produktov svobodnoradikal'nogo okislenija v kostnoj tkani i ishod dental'noj implantacii. Medicinskaja nauka i obrazovanie Urala. 2016; 1 (85): 105-7.

11. Kozlova MV, Mkrtumyan AM, Belyakova AS. Reguljacija metabolicheskih processov kosti pri dental'noj implantacii. Kremlevskaja medicina. Klinicheskij vestnik. 2018; (2): 30-9.

12. Riega-Torres JC, Villarreal-Gonzalez AJ, Ceceñas-Falcon LÁ, Salas-Alanis JC. Sjögren's syndrome (SS), a review of the subject and saliva as a diagnostic method. Gac Med Mex. 2016; 152 (3): 371-80.

13. Modi A, Morou-Bermudez E, Vergara J, et al. Validation of two point-of-care tests against standard lab measures of $\mathrm{NO}$ in saliva and in serum. Nitric Oxide. 2017; (64): 16-21. DOI: 10.1016/j. niox.2017.01.009.

14. Alkan EA, Tüter G, Parlar A, et al. Evaluation of peri-implant crevicular fluid prostaglandin levels in augmented extraction sockets by different biomaterials. Acta Odontol Scand. 2016; 74 (7): 532-8.

15. Fernandes $\mathrm{MH}$, Gomes PS. Bone Cells Dynamics during PeriImplantitis: a Theoretical Analysis. J Oral Maxillofac Res. 2016; 7 (3): e6.

\section{Литература}

1. Aziz S. Hard and soft tissue surgical complications in dental implantology. Oral Maxillofac. Surg Clin North Am. 2015; 27 (2): 313-8.

2. Guobis Z, Pacauskiene I, Astramskaite I. General diseases influence on peri-implantitis development: a systematic review. J Oral Maxillofac Res. 2016; 7 (5): 9-14.

3. Lohmann $\mathrm{CH}$, Rampal S, Lohrengel M, Singh G. Imaging in periprosthetic assessment: an orthopaedic perspective. EFORT Open Rev. 2017; 2 (5): 117-25.

4. Greenstein G, Carpentieri J, Cavallaro J. Nerve damage related to implant dentistry: incidence, diagnosis, and management. Compend Contin Educ Dent. 2015; 36 (9): 652-9.

5. Alikhasi M, Alsharbaty MHM, Moharrami M. Digital Implant Impression Technique Accuracy: A Systematic Review. Implant Dent. 2017; 26 (6): 929-35. DOI: 10.1097/ID.0000000000000683.

6. Атрушкевич В. Г., Школьная К. Д. Особенности минерального и костного обмена у пациентов в зависимости от характера течения пародонтита. Лечение и профилактика. 2017; 2 (22): 85-92.

7. Alrabeah GO, Brett P, Knowles JC, Petridis $\mathrm{H}$. The effect of metal ions released from different dental implant-abutment couples on osteoblast function and secretion of bone resorbing mediators. $J$ Dent. 2017; 66: 91-101. DOI: 10.1016/j.jdent.2017.08.002.

8. Boronat-Catala M, Catala-Pizarro M, Bagan Sebastian J. Salivary and crevicular fluid interleukins in gingivitis. J Clin Exp Dent. 2014; 6 (1): 175-9.

9. Casado PL, Aguiar DP, Costa LC. Different contribution of BRINP3 gene in chronic periodontitis and periimplantitis: a cross-sectional study. BMC Oral. Health. 2015; (15): 33. DOI 10.1186/s12903015-0018-6.

10. Плюхин Д. В. Содержание продуктов свободнорадикального окисления в костной ткани и исход дентальной имплантации. Медицинская наука и образование Урала. 2016; 1 (85): 105-7.

11. Козлова М. В., Мкртумян А. М., Белякова А. С. Регуляция метаболических процессов кости при дентальной имплантации. Кремлевская медицина. Клинический вестник. 2018; (2): 30-9.

12. Riega-Torres JC, Villarreal-Gonzalez AJ, Ceceñas-Falcon LÁ, Salas-Alanis JC. Sjögren's syndrome (SS), a review of the subject and saliva as a diagnostic method. Gac Med Mex. 2016; 152 (3): $371-80$.

13. Modi A, Morou-Bermudez E, Vergara J, et al. Validation of two point-of-care tests against standard lab measures of $\mathrm{NO}$ in saliva and in serum. Nitric Oxide. 2017; (64): 16-21. DOI: 10.1016/j. niox.2017.01.009.

14. Alkan EA, Tüter G, Parlar A, et al. Evaluation of peri-implant crevicular fluid prostaglandin levels in augmented extraction sockets by different biomaterials. Acta Odontol Scand. 2016; 74 (7): 532-8.

15. Fernandes $\mathrm{MH}$, Gomes PS. Bone Cells Dynamics during PeriImplantitis: a Theoretical Analysis. J Oral Maxillofac Res. 2016; 7 (3): e6. 